\title{
Strong downdrafts preceding rapid tropopause ascent and their potential to identify cross-tropopause stratospheric intrusions
}

\author{
Feilong Chen ${ }^{1}$, Gang Chen ${ }^{1}$, Chunhua Shi ${ }^{2}$, Yufang Tian $^{3}$, Shaodong $\mathrm{Zhang}^{1}$, and Kaiming Huang ${ }^{1}$ \\ ${ }^{1}$ School of Electronic Information, Wuhan University, Wuhan 430072, China \\ ${ }^{2}$ Key Laboratory of Meteorological Disaster, Ministry of Education, Nanjing University of Information Science \\ \&Technology, Nanjing 210044, China \\ ${ }^{3}$ Key Laboratory of Middle Atmosphere and Global Environment Observation, Institute of Atmospheric Physics, \\ Chinese Academy of Sciences, Beijing 100029, China
}

Correspondence: Gang Chen (g.chen@whu.edu.cn)

Received: 3 July 2018 - Discussion started: 11 July 2018

Revised: 6 October 2018 - Accepted: 8 October 2018 - Published: 19 October 2018

\begin{abstract}
The capability of measuring three-dimensional wind and tropopause structure with relatively high time and vertical resolution makes very-high-frequency (VHF) radars a potentially important tool for studying various processes of the atmosphere. However, at present several unanswered questions remain regarding the use of VHF radars to identify possible stratospheric intrusions. Here the potential detection of stratospheric intrusion events is discussed using the Beijing MST (mesosphere-stratospheretroposphere) radar located at Xianghe $\left(39.75^{\circ} \mathrm{N}, 116.96^{\circ} \mathrm{E}\right)$. During the passage of a cutoff low in late November 2014, a deep V-shaped tropopause structure and strong downdrafts $\left(>0.8 \mathrm{~m} \mathrm{~s}^{-1}\right)$ immediately preceding the rapid tropopause ascent $\left(>0.2 \mathrm{~km} \mathrm{~h}^{-1}\right)$ were observed. Within the height region of the downdrafts, the stability of the radar tropopause seems to be weakened. Analysis results from global reanalysis and the satellite data, as well as the trajectory model, have shown clear evidence of downward stratospheric intrusions (dry ozone-rich and depleted methane air) associated with the strong downdrafts. A total of 20 typical cases of such strong downdrafts, occurring during various synoptic processes in different seasons, have been presented, and 15 of them are exactly associated with some form of stratospheric intrusions. Four years (2012-2015) of such downdrafts are further discussed. The observations reveal that the strong downdrafts preceding the rapid tropopause ascent can be a valuable diagnostic for monitoring intrusion events, which helps us to gain a better understanding of stratospheric intrusions in VHF radar observations.
\end{abstract}

\section{Introduction}

The tropopause is a stable transition zone separating the stably stratified stratosphere from the active free troposphere. The stratospheric and tropospheric air are remarkably different in their chemical and dynamical characteristics. The stratosphere is dominantly high in ozone and potential vorticity (PV) content and low in water vapor (WV) and methane $\left(\mathrm{CH}_{4}\right)$ concentration, while the troposphere is the opposite (Holton et al., 1995). Consequently, the natural stable tropopause layer, characterized by strong gradients of trace constituents and wind speeds, plays an important role in stratosphere-troposphere exchange (STE) processes. In other words, the layer is a significant barrier for the atmospheric transport between stratosphere and troposphere (Mahlman, 1997). From a long-term point of view, the seasonal variation of the tropopause height determines the seasonal variation of the flux of stratospheric air into the free troposphere (Appenzeller et al., 1996). Under global climate warming (e.g., the continuing rise in $\mathrm{CO}_{2}$ ), the tropopause variation is also a significant factor that must be considered with regards to the recovery of the stratospheric ozone (Butchart et al., 2010; Chipperfield et al., 2017). On the other hand, the short-term tropopause variability is sensitive to various mesoscale and small-scale atmospheric processes, during which the folding or intrusion events commonly occur. This characteristic of the tropopause change is sometimes directly used to detect the tropopause folds (e.g., Rao et al., 2008; Alexander et al., 2012, and references therein), but is less often, if at all, directly used to identify stratospheric intrusions. 


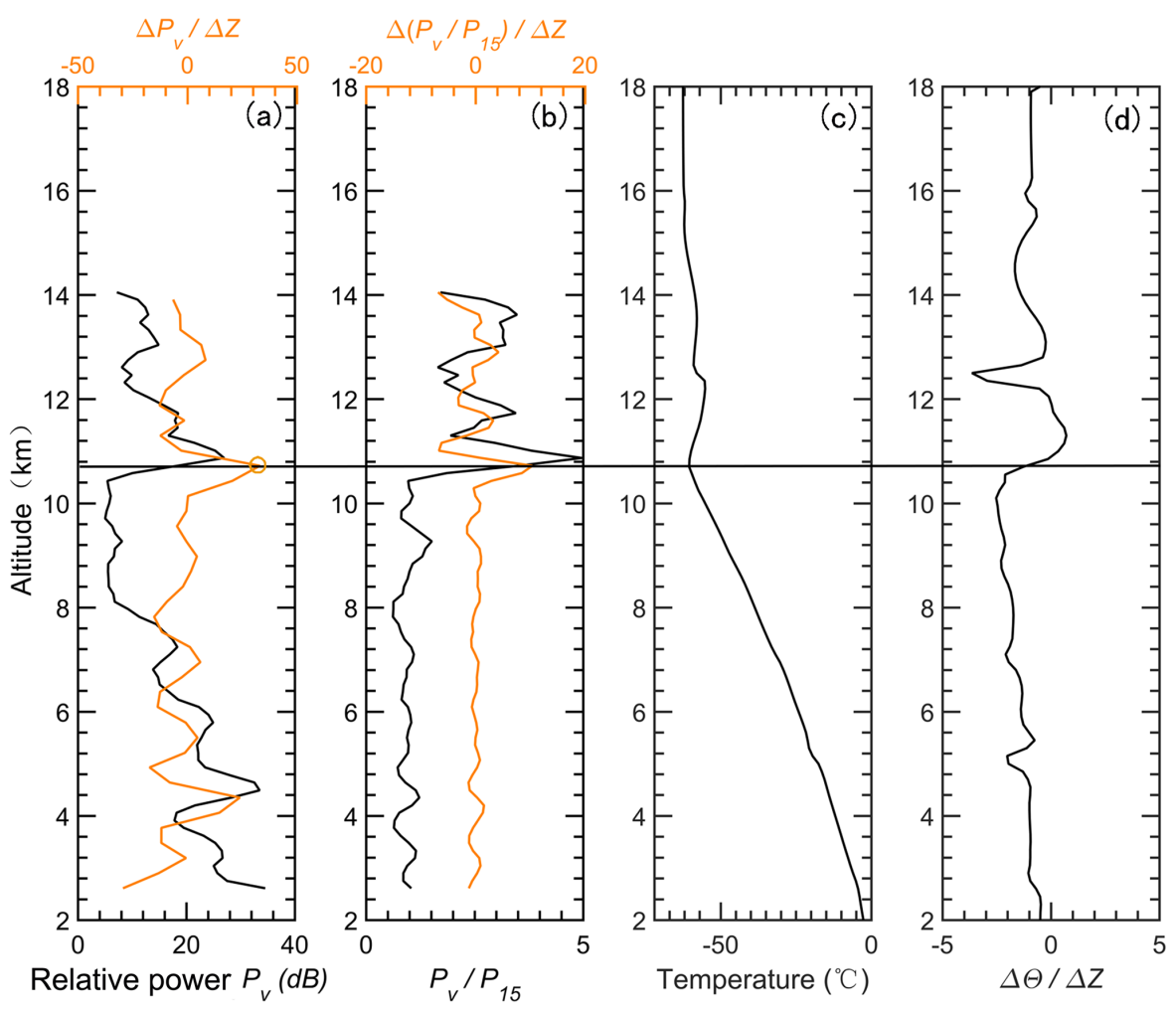

Figure 1. Example of the vertical height profiles of (a) the relative radar echo power (black line, smoothed by a three-point running mean) along with its gradient variation (orange line), (b) the aspect sensitivity (black line, expressed as the ratio between the vertical echo power and oblique echo power) along with its gradient variation (orange line), observed on 12:00 UT 29 November 2014. The vertical profiles of simultaneous radiosonde-observed temperature and potential temperature gradient are shown in plots (c) and (d). The black horizontal line denotes the LRT height derived from the radiosonde temperature profile. The orange circle indicates the RT height derived from the profile of the radar backscattered echo power.

More detailed analysis of the variability of high-resolution tropopause height and of course some other parameters (e.g., three-dimensional wind), and how the stratospheric air is transported across the tropopause into the troposphere, will help us to obtain a better understanding of the downward stratospheric intrusions (e.g., Sprenger et al., 2003; Leclair de Bellevue et al., 2007; Das et al., 2016).

Although photochemical production within the troposphere is the main source of tropospheric ozone, the influence of downward stratospheric intrusions on tropospheric ozone content cannot be ignored (Oltmans and Levy II, 1992; Stevenson et al., 2006). Stratospheric intrusions bring dry ozone-rich air down into the free troposphere (e.g., Stohl et al., 2000; Sørensen and Nielsen, 2001) and sometimes even deep to the surface (e.g., Gerasopoulos et al., 2006; Grant et al., 2008; Jiang et al., 2015; Das et al., 2016). By now, it is well established that these intrusions of stratospheric origin will significantly influence other trace gases (such as hydroxyl $(\mathrm{OH})$ ) in the troposphere (Holton et al., 1995). These influences then will further contribute to the change of radiative balance (Ramaswamy et al., 1992) and play an important role in the radiative forcing of global climate change (Holton
Table 1. Operating parameters in low-mode data of the Beijing MST radar.

\begin{tabular}{ll}
\hline Radar parameter & Value \\
\hline Transmitted frequency & $50 \mathrm{MHz}$ \\
Antenna array & $24 \times 24$ three-element Yagi \\
Antenna gain & $33 \mathrm{~dB}$ \\
Transmitter peak power & $172.8 \mathrm{~kW}$ \\
Code & 16 -bit complementary \\
No. coherent integrations & 128 \\
No. fast Fourier transform points & 256 \\
No. spectral average & 10 \\
Pulse repetition period & $160 \mu \mathrm{s}$ \\
Half power beam width & $3.2^{\circ}$ \\
Pulse length & $1 \mu \mathrm{s}$ \\
Range resolution & $150 \mathrm{~m}$ \\
Temporal resolution & $30 \mathrm{~min}$ \\
Off-zenith angle & $15^{\circ}$ \\
\hline
\end{tabular}

et al., 1995). It is true that stratospheric intrusion events occur all over the world and in any season. However, they are highly episodic in both vertical and isentropic (horizontal) directions (Chen, 1995). Various dynamical and physical pro- 


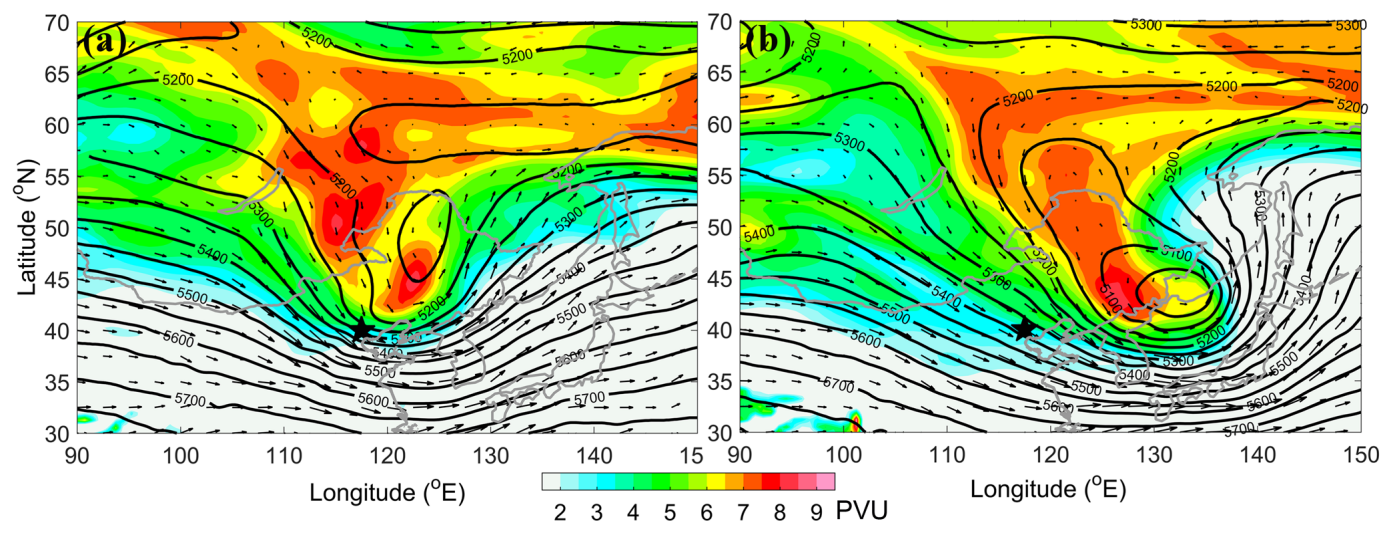

Figure 2. ECMWF-derived isentropic PV map on $315 \mathrm{~K}$ surface ( (contoured every $50 \mathrm{~m}$ in solid line) along with the wind vector (arrow) at $500 \mathrm{hPa}(\sim 5.5 \mathrm{~km}$ a.s.1.) on (a) 18:00 UTC $30 \mathrm{November} 2014$ and (b) 12:00 UTC 1 December 2014. The black star shows the location of Xianghe.
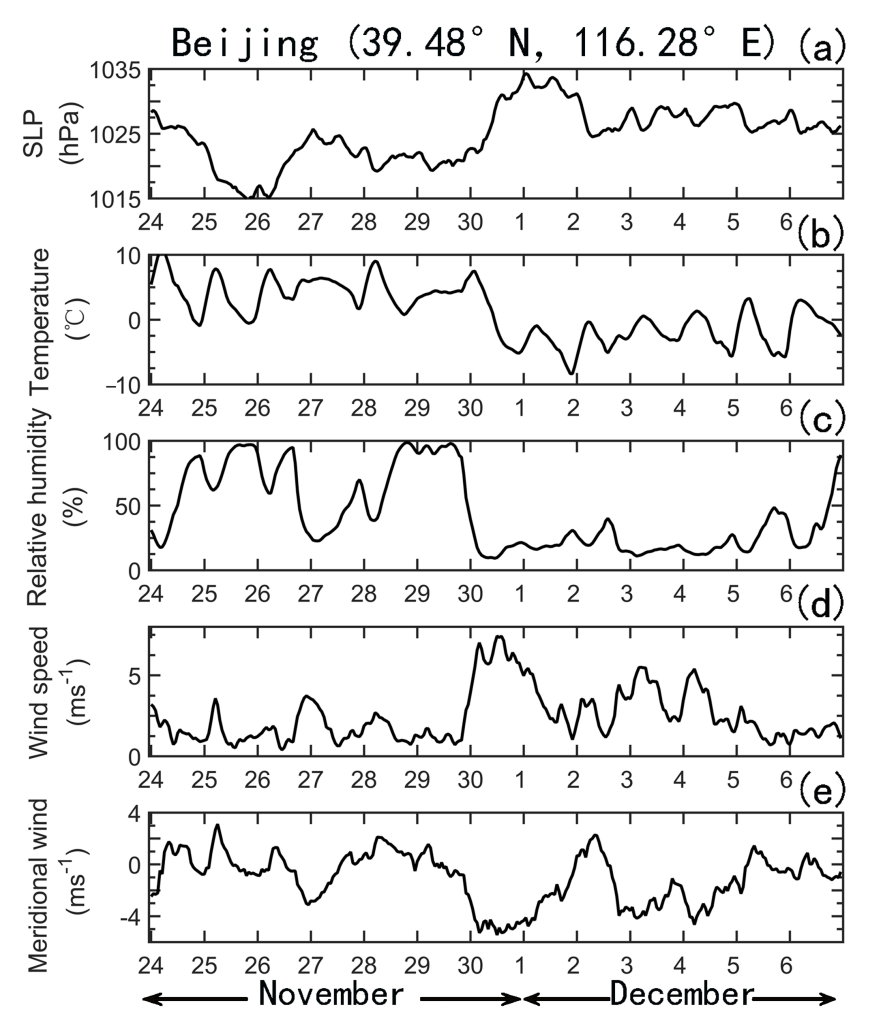

Figure 3. Time series of surface ( $\sim 1.2 \mathrm{~m}$ above the surface) hourly meteorological measurements of (a) sea level pressure, (b) temperature, (c) relative humidity, (d) horizontal wind, and (e) meridional wind during the period 24 November-6 December 2014, observed over the Beijing station (39.4 $\mathrm{N}, 116.2^{\circ} \mathrm{E} ; 31.3 \mathrm{~m}$ a.s.1.).

cesses have been proposed to be responsible for extratropical intrusion events. These mainly include tropopause folds, stratospheric streamers and break-up, cutoff lows (COLs), wave breaking, and mesoscale convective activities and thunderstorms (Stohl et al., 2003).
The certain dynamical and chemical characteristics of stratospheric air allow the tracers, such as dry ozone-rich and high PV, to be proper indicators for the intrusions penetrating down into the troposphere. Based on these tracers, various tools are available to detect intrusion events. Balloon-borne ozonesonde sounding is an effective tool to make measurements of ozone with high vertical resolution, but is limited by coverage (He et al., 2011) and temporal resolution. In contrast, the satellite-borne remote sensing instruments, such as the Atmospheric Infrared Sounder (AIRS), can provide nearly global coverage of various trace gases but have limitations in vertical and temporal resolution. Another method for studying transport processes is the trajectory model, from which the backward trajectories can provide valuable information on the possible sources of the trace gases (e.g., Elbern et al., 1997).

By far, large-scale STE has been widely studied and is fairly well understood, but the details of small-scale intrusions still need more research (e.g., Holton et al., 1995). Kumar and Uma (2009) reported that the shortage of direct measurements of vertical winds near the tropopause may be responsible for the lack of fine-scale observations of smaller scale intrusions.

Very-high-frequency (VHF) radars, compared to the tools mentioned above, are capable of continuously monitoring the atmosphere under any weather conditions and detecting tropopause height from backscattered signal with both high temporal and spatial resolution. During the past two decades, VHF radar measurements have commonly been used to assist in the study of stratospheric intrusions (e.g., Hocking et al., 2007; Das et al., 2016). However, it still remains uncertain in many aspects when only using the VHF radar to identify intrusion events, especially the criteria for the identification. Complicated and changeable atmospheric processes make it difficult to identify the intrusion events by only radar data. Hocking et al. (2007) reported that the rapid ascent in 

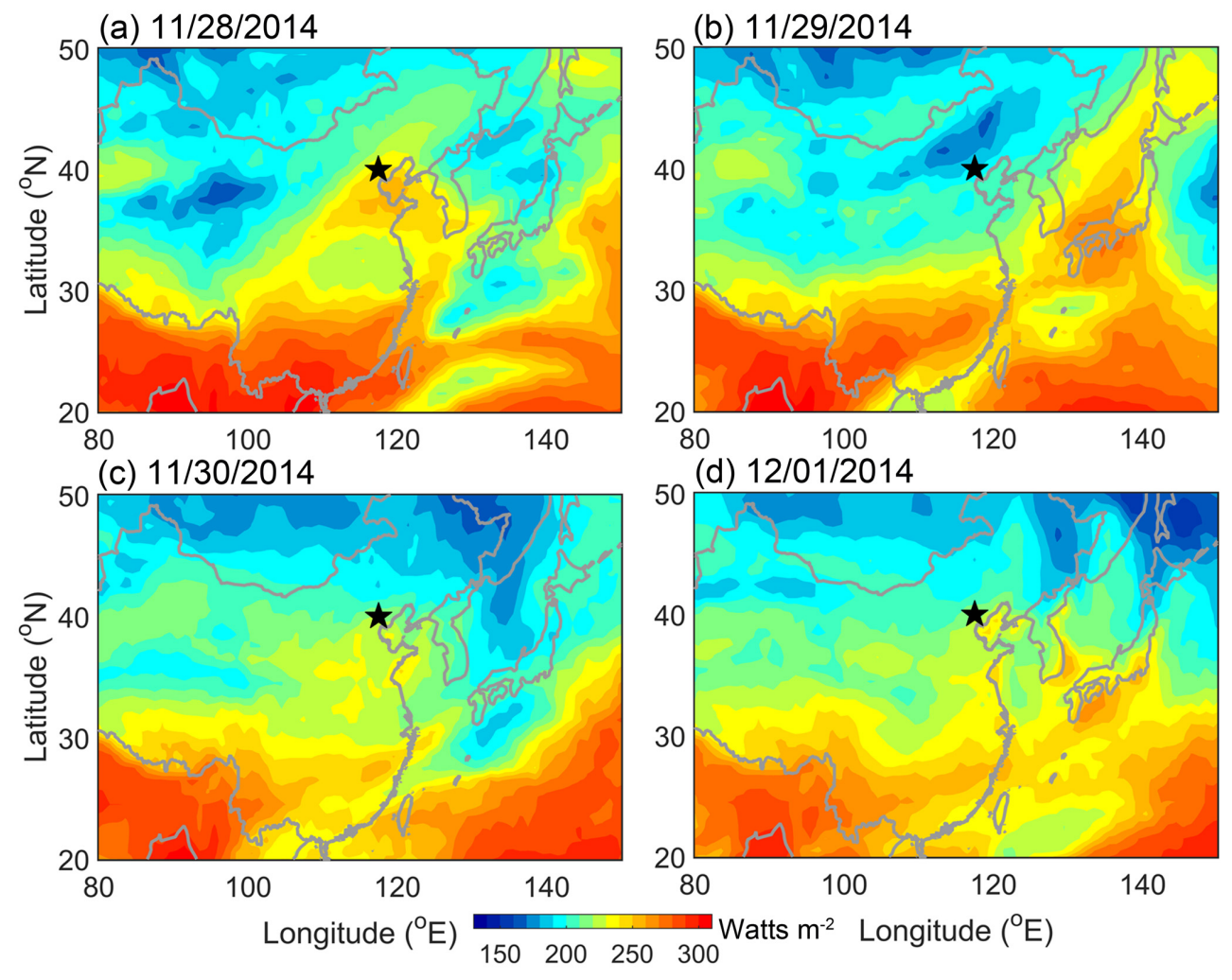

Figure 4. Contour maps of the high-quality Climate Data Record (CDR) of the daily outgoing longwave radiation (OLR), derived from the NOAA high-resolution infrared radiation sounder (HIRS) on (a) 28 November, (b) 29 November, (c) 30 November, and (d) 1 December 2014. The black star shows the location of Xianghe.

radar-derived tropopause (RT) altitude $\left(>0.2 \mathrm{~km} \mathrm{~h}^{-1}\right)$ can be a valuable diagnostic for possible stratospheric intrusions. Their observation results clearly indicate that almost every occurrence of definite stratospheric intrusion is related to a definite RT ascent $\left(>0.2 \mathrm{~km} \mathrm{~h}^{-1}\right.$, occurred at or just before the intrusion). The reverse is also reasonable; that is, almost every occurrence of definite RT ascent is associated with some form of intrusion (Hocking et al., 2007). Please note that we do not mean that the tropopause ascent is the best and most accurate diagnostic that can be used directly for identifying possible intrusions. As motivated by the study of Hocking et al. (2007), tropopause ascent is one of the key objects in this study.

Only using the information of RT height variability is, of course, insufficient for quantifying intrusion events accurately using radar data. Therefore, radar measurements of vertical motions are also considered simultaneously to discuss the possible capability of radar measurements for identifying cross-tropopause stratospheric intrusions, which is the main point of this paper. This study is carried out mainly via a detailed case observation during a COL passage and 20 other general cases during various synoptic situations. In Sect. 2 the datasets used in this paper are described, Sect. 3 presents detailed results and discussion, and Sect. 4 gives the conclusions.

\section{Dataset}

\subsection{MST radar data and tropopause detection}

The Beijing MST (mesosphere-stratosphere-troposphere) radar located at Xianghe, China $\left(39.75^{\circ} \mathrm{N}, 116.96^{\circ} \mathrm{E} ; 22 \mathrm{~m}\right.$ above sea level), is a VHF radar operated at $50 \mathrm{MHz}$ and installed in 2010 based on the first phase of Chinese Meridian Space Weather Monitoring Project (Chinese Meridian Project for short) (Wang, 2010). The radar antenna array consists of a $24 \times 24$ three-element Yagi antenna to produce an average power aperture product of $3.2 \times 10^{8} \mathrm{Wm}^{2}$ and maximum directive gain of $34.8 \mathrm{~dB}$. It operates radiation pattern with $172 \mathrm{~kW}$ peak power and $3.2^{\circ}$ half-power beam width. More detailed information of the radar system can be found in Chen et al. (2016). Routine low-mode data were used for present study with $0.5 \mathrm{~h}$ time resolution and $1 \mu$ s coded pulse, which provides $150 \mathrm{~m}$ vertical resolution. Details of the lowmode setup used in this study are given in Table 1.

It has long been known that VHF radar reflectivity is proportional to the mean generalized refractive index gradient 

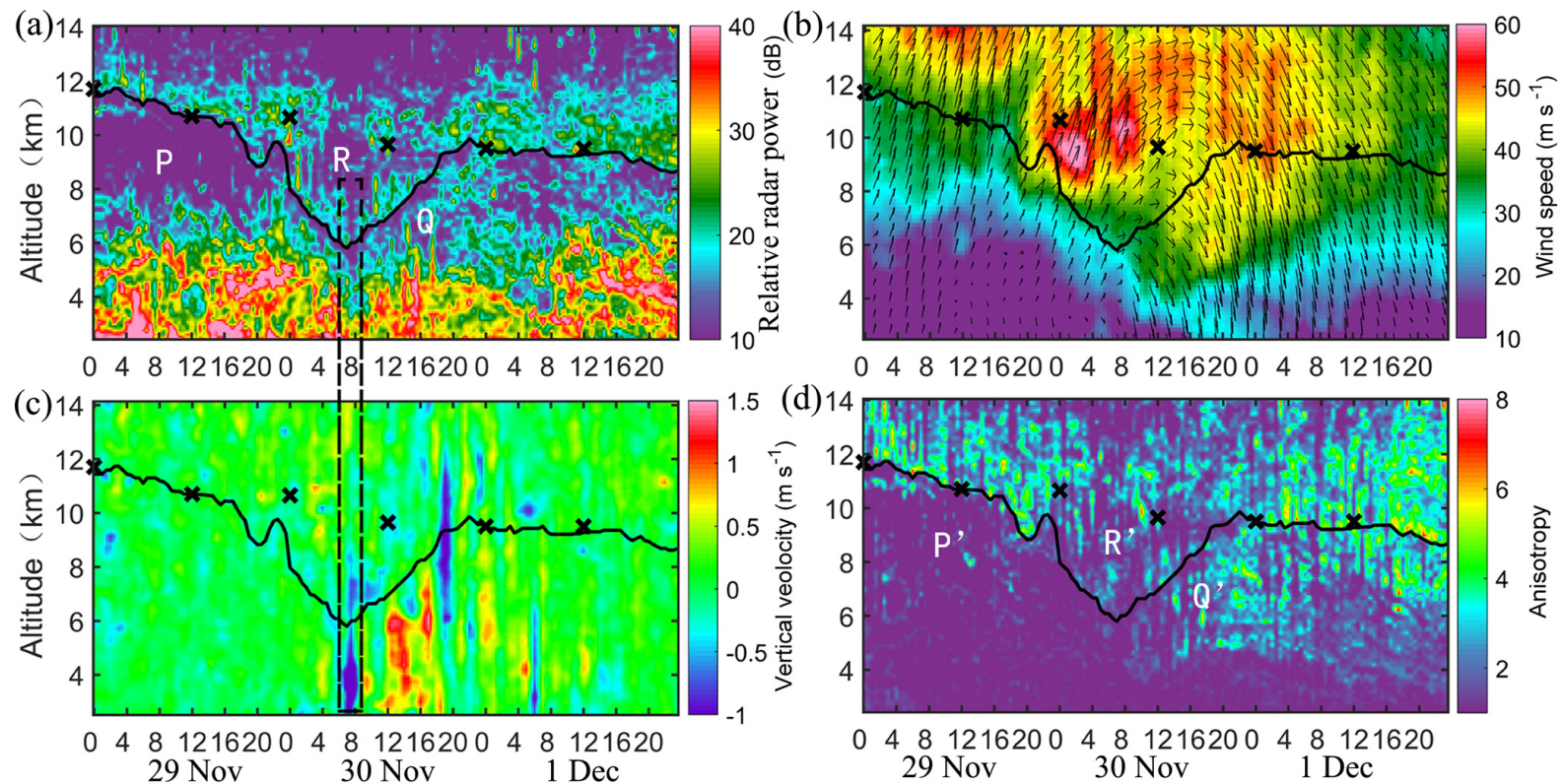

Figure 5. Altitude-time section of (a) the radar backscattered echo power in zenith direction, (b) the horizontal wind speed along with wind vector, of which the up and down arrows represent north and south, respectively, and left-right is west-east, (c) the vertical velocity, and (d) the aspect sensitivity, observed by the Beijing MST radar from 29 November to 1 December 2014. The black curve shows the radar-determined tropopause, as defined in Sect. 2.1. The dotted rectangle highlights the strong downdrafts immediately preceding the rapid tropopause ascent. The positions of the LRT tropopause heights, derived from the nearly simultaneous collocated GPS radiosonde temperature profile, are marked by crosses.
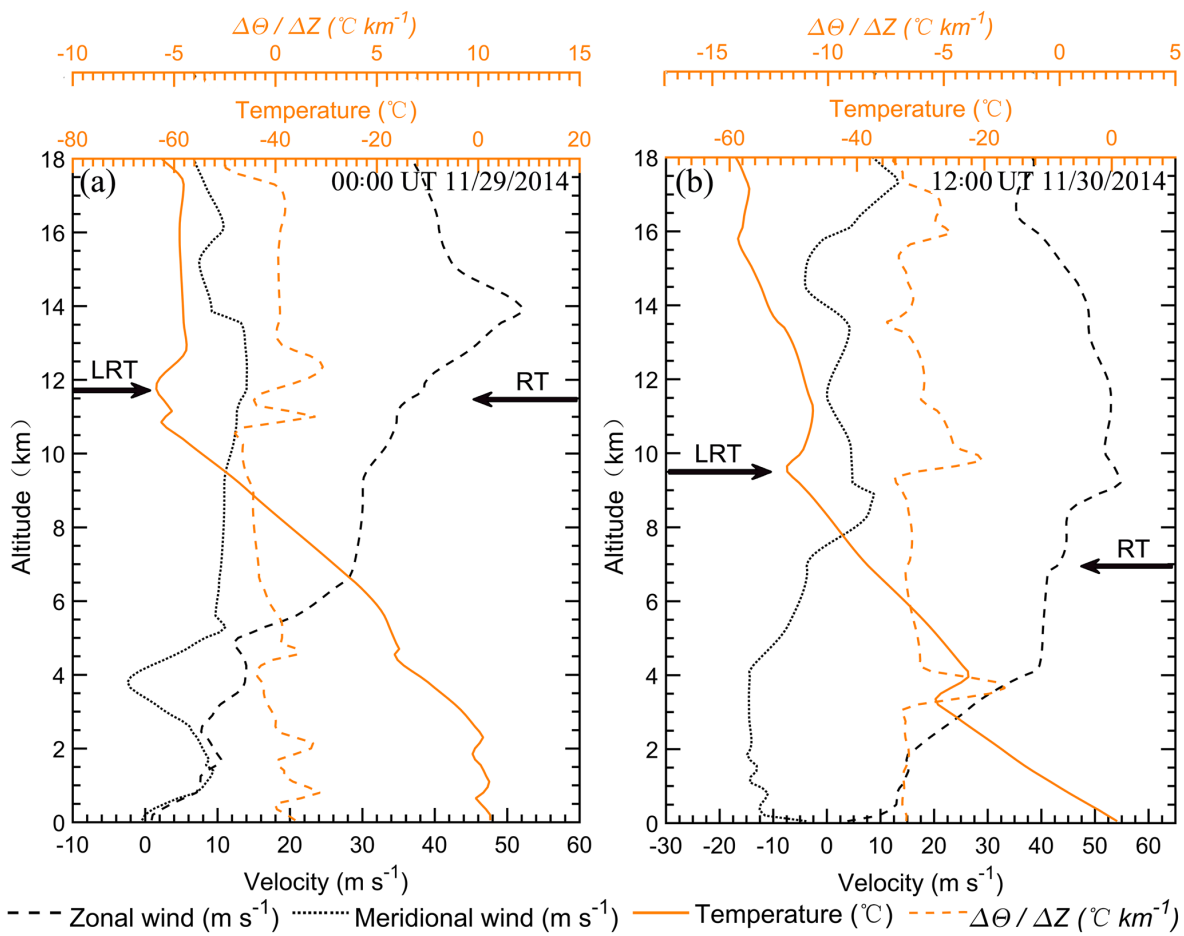

Figure 6. Vertical profiles of zonal wind, meridional wind, temperature, and potential temperature gradient derived from the GPS radiosonde measurements, at (a) 00:00 UTC 29 and (b) 12:00 UTC 30 November 2014. The bold arrows on the left and right site of each panel indicate the radiosonde-derived LRT tropopause and radar-derived tropopause height, respectively. 

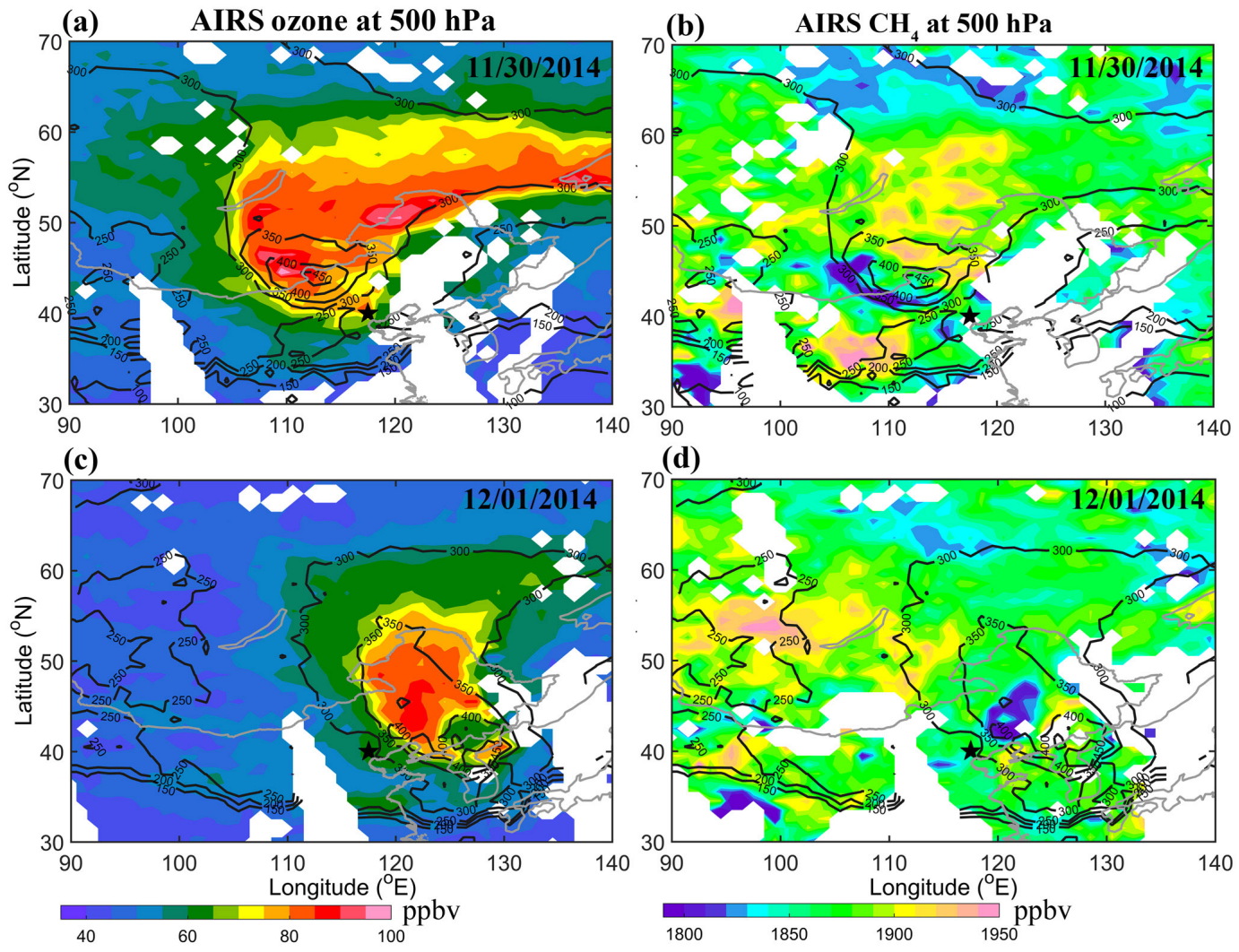

Figure 7. $500 \mathrm{hPa}$ ozone (a) and methane $\mathrm{CH}_{4}$ (b) distribution along with the tropopause height contour, derived from the AIRS satellite observations. The top and bottom plots show the data of 30 November and 1 December 2014, respectively. According to the Aqua Orbit Tracks (not shown), the time range of the satellite passage is between $\sim$ 04:00 and 07:25 on 30 November and between $\sim 03: 15$ and 06:35 on 1 December 2014. The black star indicates the location of Xianghe.

$M$, which is a function of humidity variation and static stability and is given by Ottersten (1969) as follows:

$$
\begin{aligned}
& M=-77.6 \times 10^{-6}(p / T)(\mathrm{d} \ln \theta / \mathrm{d} z) \\
& \quad \cdot 1+15500 q / T[1-(\mathrm{d} \ln q / \mathrm{d} z) /(2 \mathrm{~d} \ln \theta / \mathrm{d} z)],
\end{aligned}
$$

where $p$ is the atmospheric pressure (hPa), $T$ is the temperature $(\mathrm{K}), \theta$ is the potential temperature $(\mathrm{K})$, and $q$ is the specific humidity $\left(\mathrm{gg}^{-1}\right)$. According to the second and third terms of Eq. (1), large humidity variation contributes to the echo from the lower and middle troposphere. From the first term, the radar backscatter power is proportional to the static stability, which in fact is directly proportional to the potential temperature gradient. The tropopause, near which a strong potential temperature gradient exists, will lead to strong radar echoes in vertical incidence, as well as large radar aspect sensitivity (as shown in Fig. 1). Radiosonde data used in this paper were received from the GTS1 type digital radiosonde launched from Beijing Meteorological Observatory $\left(39.93^{\circ} \mathrm{N}, 116.28^{\circ} \mathrm{E}\right.$; station number 54511$)$, which is less than $45 \mathrm{~km}$ away from the MST radar site. The black line in Fig. 1 denotes the lapse-rate tropopause (LRT) defined using the temperature lapse rate (World Meteorological Orga- nization, 1986). Applying the characteristic (enhanced radar echoes due to partial specular reflection) mentioned above, the tropopause can be detected and its height determined by VHF radars (Gage and Green, 1979). It has received widespread application around the world, in middle latitudes (e.g., Hocking et al., 2007), polar regions (e.g., Alexander et al., 2012), and tropical regions (e.g., Yamamoto et al., 2003; Das et al., 2008). Here, the radar-determined tropopause (RT) height is defined as the height (above $500 \mathrm{hPa}$ ) at which the maximum vertical gradient of echo power is located (shown as the orange circle in Fig. 1a). This definition of RT is similar to that in the studies of Alexander et al. (2012) and Ravindrababu et al. (2014).

In the present study, the MST radar mainly provides continuous measurements of backscattered echo power, threedimensional wind, and RT height with a time resolution of $0.5 \mathrm{~h}$. In addition, the radar aspect sensitivity, expressed as the ratio between vertical $\left(p_{\mathrm{v}}\right)$ and oblique $\left(p_{\mathrm{o}}\right.$; here $15^{\circ}$ north is used) beam echo power, is mainly caused by the horizontally stratified anisotropic stable air and thus will be used as a potential signature of stratospheric intrusions in the troposphere (e.g., Kim et al., 2001). The backscattered echo power given here is expressed as relative power in decibels 
(dB). In order to reduce the random noise, the profile of $p_{\mathrm{v}}$ is smoothed by a three-point running mean in altitude. Note that the data that are heavily contaminated will be eliminated from our datasets. The data of December 2015 and September 2015 are excluded.

\subsection{AIRS satellite data}

The AIRS instrument on the NASA Aqua/EOS polar orbit satellite is a 2378-channel nadir cross-track scanning infrared spectrometer. It can provide profiles of a number of trace gases, including ozone and $\mathrm{CH}_{4}$ (Susskind et al., 2003). The footprint of these retrieval data is $45 \mathrm{~km}$ by $45 \mathrm{~km}$ and their most sensitive region is in an altitude range of 300 $600 \mathrm{hPa}$. Many studies have shown that these AIRS retrieval constituents are useful indicators for detecting stratospheric intrusions. He et al. (2011) suggested that AIRS can observe the enhanced tropospheric ozone that is of stratospheric origin. Xiong et al. (2013) reported that AIRS is capable of observing abnormal depletion in $\mathrm{CH}_{4}$ in the troposphere during intrusions. AIRS offers good latitude-longitude coverage. Here we use version 6 of the AIRS Level-3 ozone and methane retrieval products.

\subsection{Meteorological reanalysis}

European Centre for Medium-Range Weather Forecasts (ECMWF) reanalysis ERA-Interim data are also used. After November 2000 the data are based on the T511L60 version available with a $6 \mathrm{~h}$ temporal resolution and $3^{\circ} \times 3^{\circ}$, $0.125^{\circ} \times 0.125^{\circ}$ latitude-longitude grid (Dee et al., 2011) The dataset from 15 isentropic and 37 pressure levels interpolated into a $0.5^{\circ} \times 0.5^{\circ}$ grid are applied for the present study.

\subsection{HYSPLIT model}

Backward (forward) trajectories in given starting locations are capable to reproduce the sources (destinations) of the air parcel that will allow us to examine the intrusions of stratospheric origin in the troposphere (e.g., Elbern et al., 1997). The Hybrid Single Particle Lagrangian Integrated Trajectory model (HYSPLIT) developed by the National Oceanic and Atmospheric Administration (NOAA) Air Resource Laboratory (ARL) (Rolph, 2003; Stein et al., 2016) is applied to calculate the backward and forward trajectories. The calculation method of the model is a hybrid between the Lagrangian approach and the Eulerian methodology. In this paper, Global Data Assimilation System (GDAS) datasets are adopted for driving the HYSPLIT.
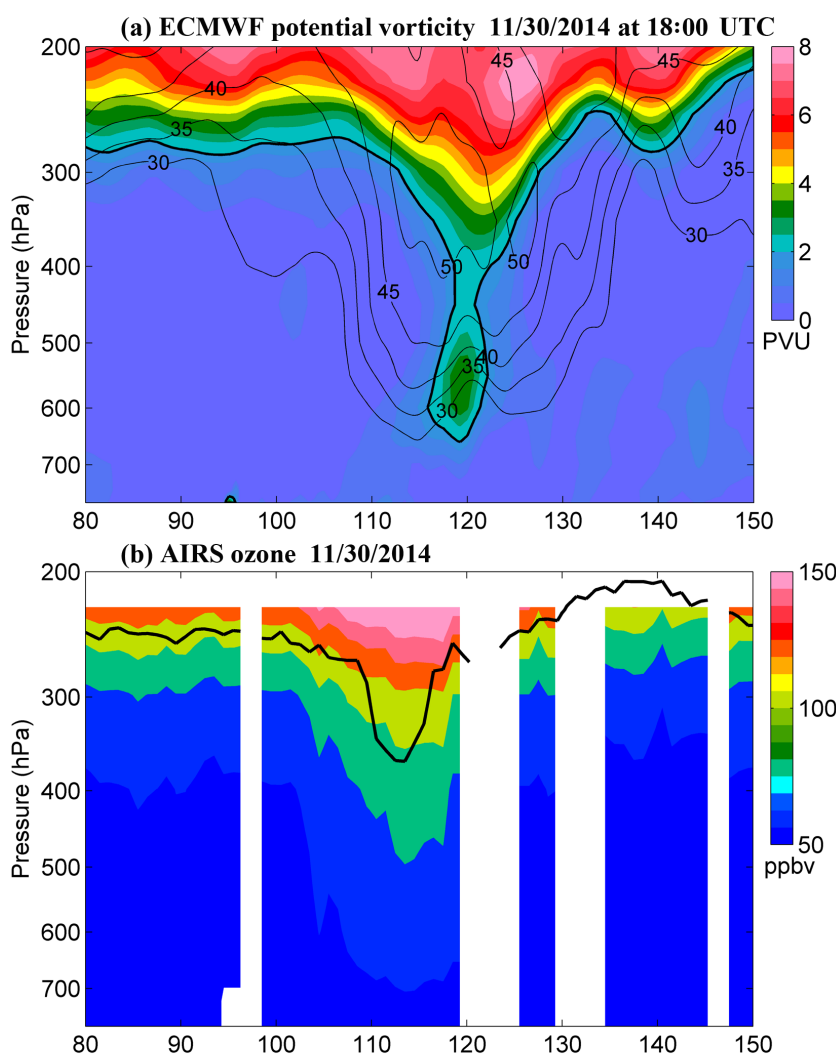

(c) ECMWF specific humidity 11/30/2014 at 18:00 UTC

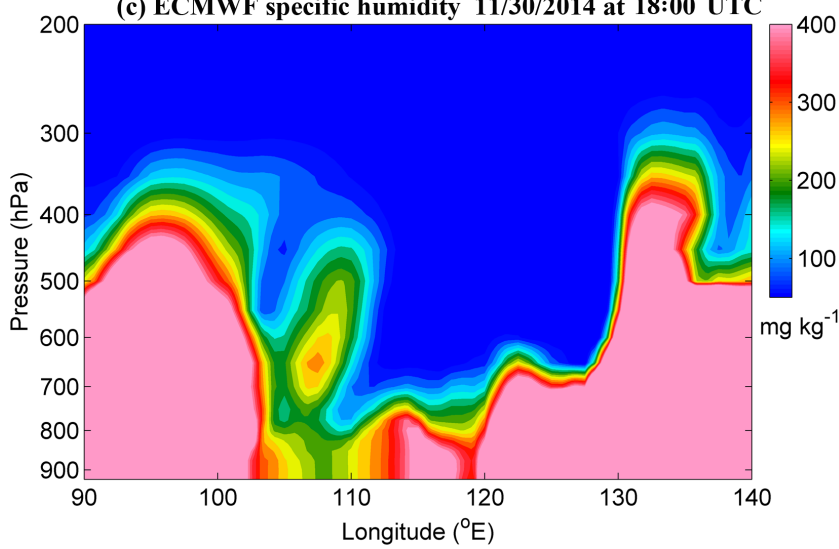

Figure 8. Longitude-pressure cross section of (a) ECMWF PV (colors, in pvu) along with horizontal wind contour (thin black line, $\mathrm{m} \mathrm{s}^{-1}$ ) at 18:00 UTC on 30 November 2014, (b) AIRS ozone mixing ratio (colors, in ppbv) along with tropopause height (black line) on 30 November 2014, and (c) ECMWF specific humidity (colors, in $\mathrm{mg} \mathrm{kg}^{-1}$ ) at 18:00 UTC on 30 November 2014, at a constant latitude of $40^{\circ} \mathrm{N}$ (nearest grid point in the latitude of Xianghe). The bold line in (a) marks the isotropic line of PV at 2 pvu. 

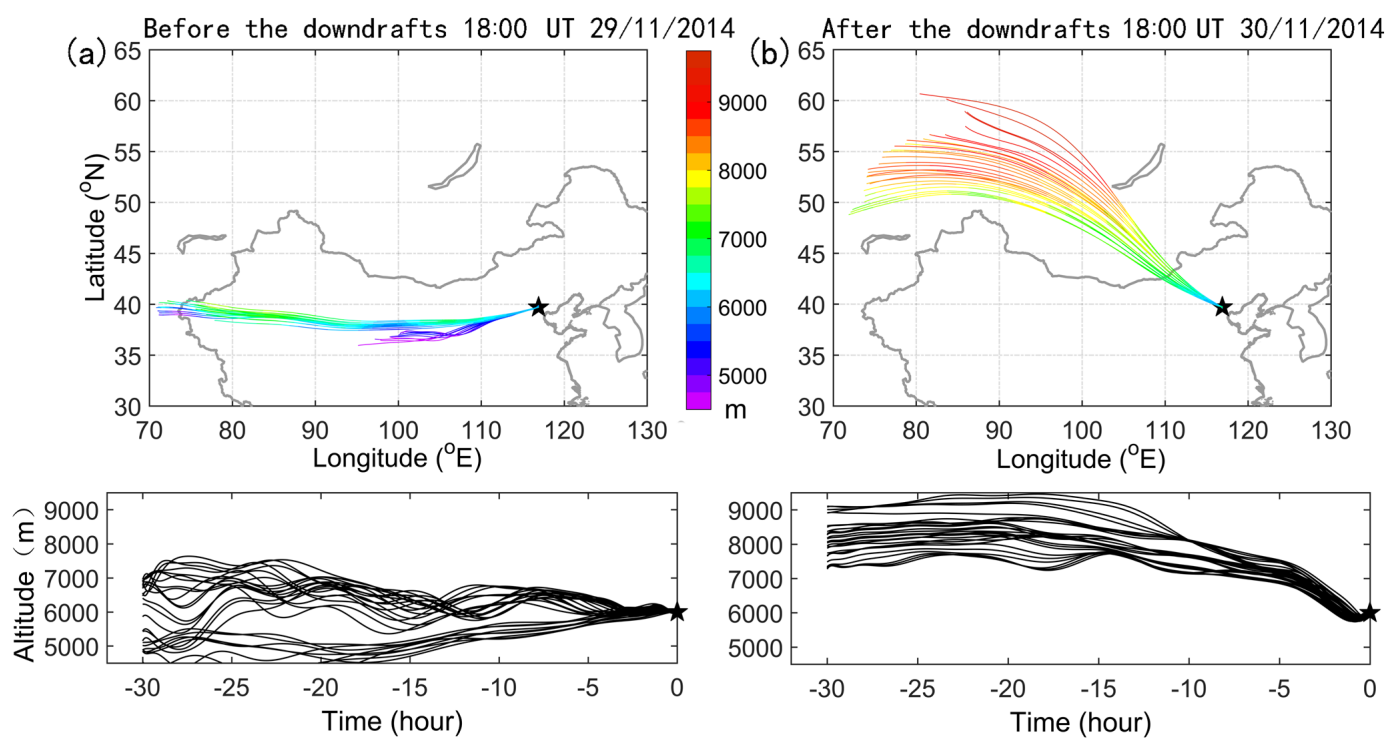

Figure 9. Illustration of $30 \mathrm{~h}$ three-dimensional backward trajectories ending at Xianghe at $6000 \mathrm{~m}$ using the National Oceanic Atmospheric Administration (NOAA) HYSPLIT model: (a) before the main downdrafts at 18:00 UTC on 29 November 2014, and (b) after the main downdrafts at 18:00 UTC on 30 November 2014. The HYSPLIT ensemble consists of 27 trajectories. The upper plots show the horizontal projection of the trajectories, and the lower plots show the corresponding time-height vertical displacement of the trajectories.
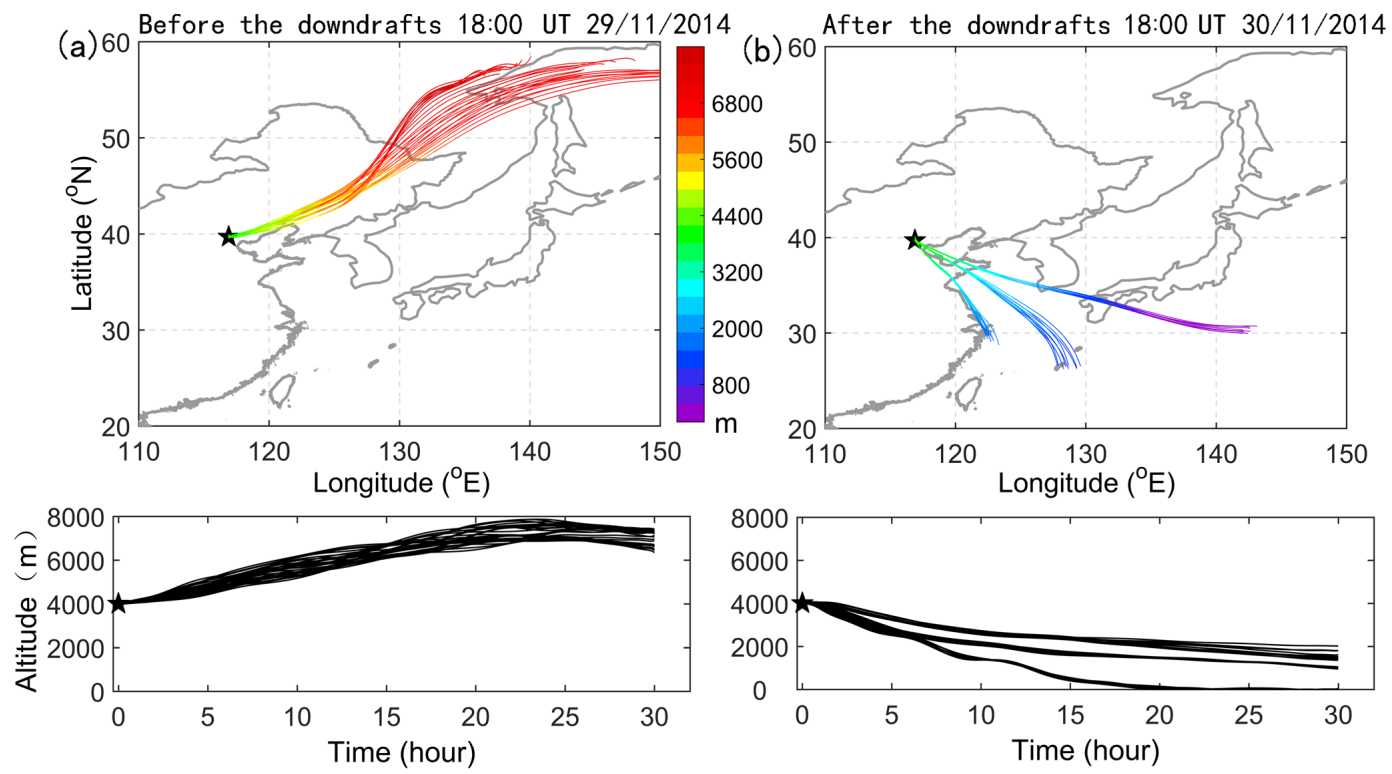

Figure 10. Same as Fig. 10 but for three-dimensional forward trajectories starting at Xianghe at $4000 \mathrm{~m}$ : (a) before the main downdrafts at 00:00 UTC on 30 November 2014, and (b) after the main downdrafts at 00:00 UTC on 1 December 2014.

\section{Results and discussion}

\subsection{Meteorological synoptic situation}

On the morning of 29 November 2014, a $500 \mathrm{hPa}$ trough developed on the western site of Lake Baikal (western Siberia). The trough moved southeastward and extended equatorward and its southern tip separated from the westerlies in the af- ternoon of 30 November 2014 (Fig. 2b), forming a COL near the radar site as shown by the closed geopotential contour. The black stars in Fig. 1 and other figures indicate the location of the radar site. On the following days, the COL system moved northeastward gradually (Fig. 2b) and finally stayed over eastern Russia near Sakhalin Island until it reconnected and merged to the westerly flow. $315 \mathrm{~K}$ isentropic PV patterns have shown the coarse-resolution features of intrusions 
from the polar reservoir across the tropopause into the midlatitude troposphere. The PV streamer curved and rolled up cyclonically along the western flank of the COL (Fig. 2b).

Figure 3 shows the time series of hourly surface meteorological parameters over the Beijing station. The data are obtained from the Chinese National Meteorology Information Center, less than $50 \mathrm{~km}$ from the MST radar site. As the dry cold air invasion accompanied by the COL traveled deeply into the planetary boundary layer, it brought severe weather to the surface, including a rapid decrease in temperature and humidity and a rapid increase in surface wind and sea level pressure. The humidity decreased from $\sim 85 \%$ to $12 \%$ within less than $8 \mathrm{~h}$. It is well established that the polartype COLs have strong potential to trigger deep convection (Price and Vaughan, 1993). To examine the potential convection, maps of high-quality Climate Data Record (CDR) of daily outgoing longwave radiation (OLR) (Lee, 2014) are displayed in Fig. 4. During the development of the COL, a local region with an abnormal low OLR value was clearly observed near the radar site on 29 November (Fig. 4b). The satellite-observed cloud top temperature also showed the low values corresponding to the low OLR (figure not shown), indicating that convection may be generated near the radar site on 29 November. Please note that we did not observe such a low value either in OLR (Fig. 4c, d) or in cloud top temperature near the radar site on 30 November and 1 December. The time for all the observations in this paper is shown in universal time (UTC) which is $8 \mathrm{~h}$ behind Beijing standard time $(\mathrm{LT}=\mathrm{UTC}+8)$.

\subsection{MST radar observations}

Radar echo power, horizontal wind vector, vertical wind, and radar aspect sensitivity are plotted in Fig. 5 as a function of height and time during the passage of the COL. Time variation of RT (black line) and LRT (black crosses) heights are also displayed. The RT height first experienced a rapid descent, and then increased rapidly, forming a deep V-shaped structure of $\sim 4 \mathrm{~km}$ depth. The vertical velocity of the RT height variation (both the rapid descent and ascent branches) reaches up to $0.28 \mathrm{~km} \mathrm{~h}^{-1}$. The rapid RT variation in altitude is in fact the response of the tropopause fold below the jet stream, which is represented well in Fig. 8a. Rapid variation in RT height created a region with low echo power (marked by $R$ on Fig. 5a) and low aspect sensitivity (marked by $R^{\prime}$ on Fig. 5d), for which one would normally expect to find a high value within the "normal" tropopause layer. Unlike the RT height, the radiosonde LRT altitudes are nearly constant during the COL passage. In normal conditions, RT agrees well with the LRT altitude, such as indicated by Fig. 6a. However, large differences, of the order of $2.5 \mathrm{~km}$ (as shown in Fig. $6 \mathrm{~b}$ at 12:00 UTC 30 November), are observed between LRT and RT in altitude during the passage of the COL as expected. It is the difference in definition that contributes most to the large differences, especially under the tropopause fold con- ditions (e.g., Yamamoto et al., 2003; Fukao et al., 2003). It is worth noting that, in Fig. 6b, although there is no clear reversion in the radiosonde temperature profile within the height of RT, the RT height corresponds well to the reversion of zonal and meridional wind and potential temperature gradient. Such differences between RT and LRT heights can commonly be observed, especially during extreme synoptic situations such as cyclones (e.g., Alexander et al., 2012).

The most important observation in this detailed case experiment is the strong downdrafts (hereinafter inferred to as main downdrafts) observed immediately preceding the rapid RT ascent (Fig. 5c). The radar echo power sharply weakened (dotted rectangle in Fig. 5a) and the wind direction changed rapidly (Fig. 5b; change from dominant southerly wind to dominant northerly jet) within the height region of the main downdrafts. As mentioned previously, an abnormal low value in OLR and cloud top temperature indicates the possible occurrence of convective activity on 29 November, but nothing significant appeared on 30 November near the radar site. Consequently, we preliminarily consider that the main downdrafts that occurred near 07:00 UT 30 November might not be produced directly by convective activity. Here, the accurate origin of the main downdrafts will not be discussed in detail, and it is also beyond the scope of present study.

The research by Hocking et al. (2007) has suggested that the rapid ascent in RT height $\left(>0.2 \mathrm{~km} \mathrm{~h}^{-1}\right)$ can be a valuable diagnostic for the occurrence of stratospheric intrusions. Here in this paper, the main downdrafts preceding the rapid RT ascent observed by the Beijing MST radar are thus suspected to be an important feature or response of some form of vertical stratospheric intrusions. Firstly, as the tropopause descends (folded downward), it will displace stratospheric air into the troposphere (e.g., Hoskins et al., 1985). Secondly, the main downdrafts will act as an effective way to weaken the tropopause by means of continuously impinging on the tropopause, through which the stratospheric air is permitted to penetrate down into the free troposphere (e.g., Hirschberg and Fritsch, 1993; Kumar, 2006). In addition, after the main downdrafts, the observed region near the upper troposphere with strong backscatter echoes (marked by $Q$ ) and especially with abnormal high aspect sensitivity (marked by $Q^{\prime}$ ) may also be a weak signature of the possible intrusions. In normal conditions, they are usually low in value in the upper troposphere (such as the region marked by $P$ and $P^{\prime}$ ). As we mentioned before, a large value in radar aspect sensitivity is mainly caused by reflection from the stable atmospheric layer, such as the tropopause or lower stratosphere. When stable stratospheric air intrudes into the troposphere and without mixing with the surrounding air mass, the intrusions in the free troposphere will be reflected as abnormal large aspect sensitivity. Further direct evidence of the relevant intrusions in dynamical and chemical aspects will be demonstrated in the next section, using satellite AIRS and global reanalysis data. 


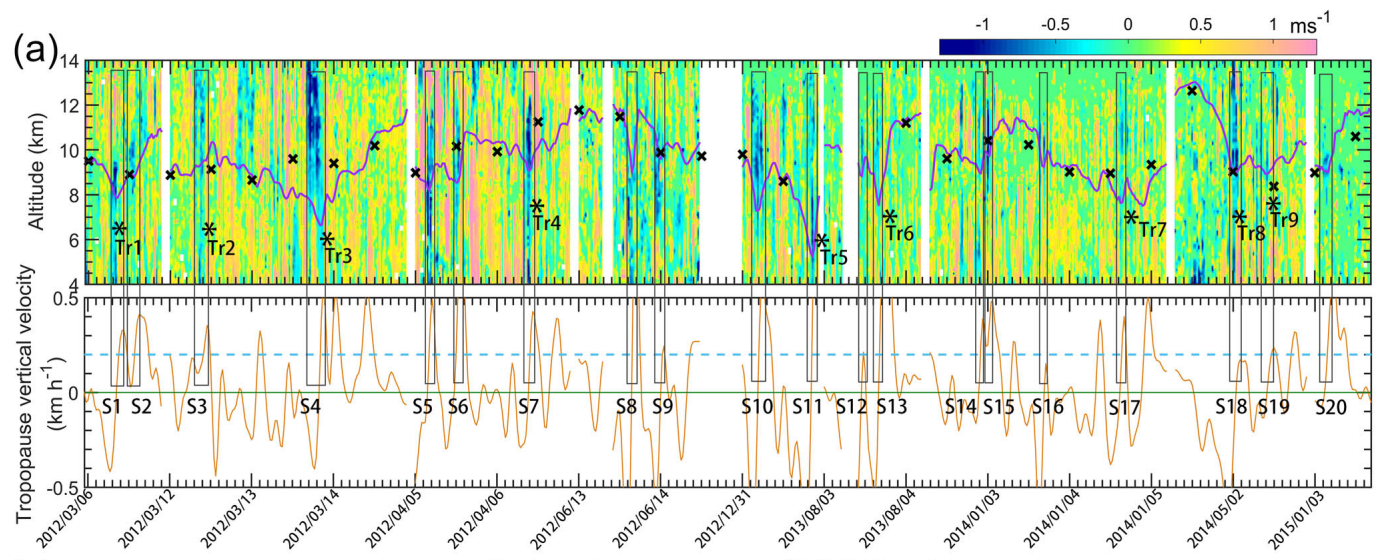

(b)

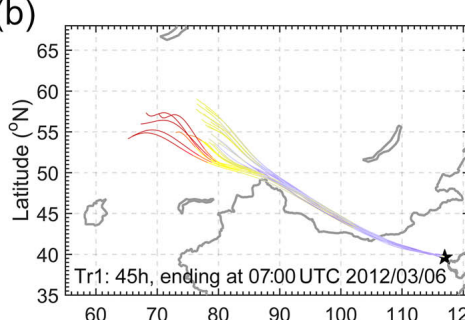

Backward trajectories using HYSPLIT model
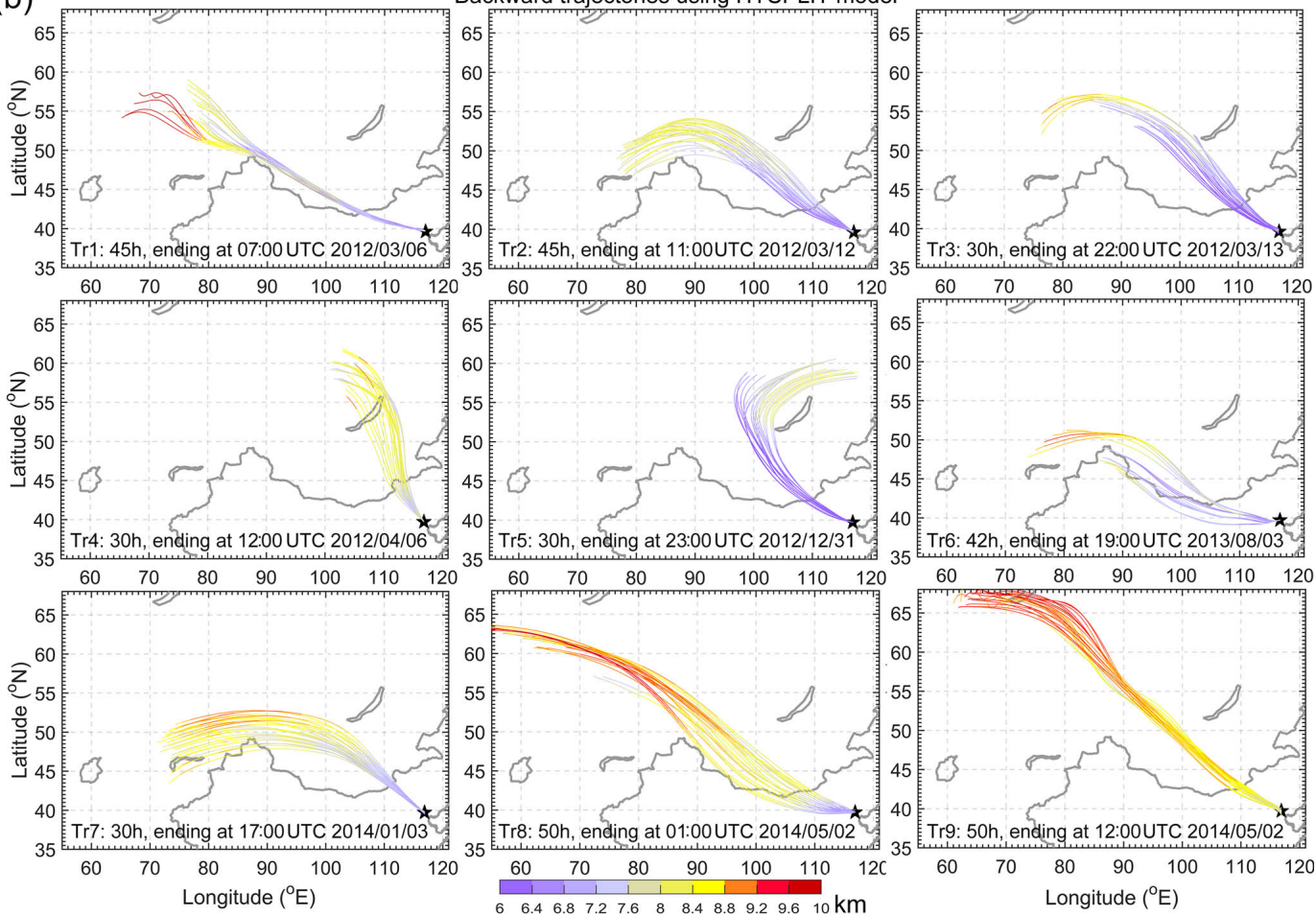

Figure 11. (a) Height-time section of several episodic observations of the radar-derived vertical wind (colors in $\mathrm{m} \mathrm{s}^{-1}$ ) along with RT height (purple bold line) and LRT height (bold crosses), between March 2012 and January 2015. The corresponding vertical velocity of the RT (orange line) is plotted in the lower panel of (a); the dotted blue line indicates the value of $0.2 \mathrm{~km} \mathrm{~h}^{-1}$. Dates for the observations are displayed as year/month/day. Black rectangular boxes represent the cases of strong downdraughts (absolute value $\geq 0.5 \mathrm{~m} \mathrm{~s}^{-1}$ ) preceding rapid tropopause ascent $\left(>0.1 \mathrm{~km} \mathrm{~h}^{-1}\right)$ and are labeled as S1, S2, S3, .., S20. The symbol “*”, labeled $\operatorname{Tr} 1-\operatorname{Tr} 9$, indicates the ending point of the corresponding trajectories in Fig. 12b. (b) Results of backward trajectories (colors in km) of the nine typical selected cases from Fig. 12a, providing the signature and source of possible stratospheric intrusions.

\subsection{Associated stratospheric intrusions}

Due to the sensitivity of the AIRS, retrieved ozone and $\mathrm{CH}_{4}$ is between 300 and $600 \mathrm{hPa}$. Figure 7 shows the $500 \mathrm{hPa}$ distribution of AIRS-observed ozone and $\mathrm{CH}_{4}$, along with the AIRS tropopause contour (defined based on the temperature lapse rate). The ozone distribution maps (Fig. 7a and c) clearly show a large area with enhanced tropospheric ozone (>80 ppbv) near the radar site during the passage of the COL.
Moreover, severe $\mathrm{CH}_{4}$ depletion ( $<1840 \mathrm{ppbv}$ ) was also observed (Fig. $7 \mathrm{~b}$ and d). These features of the ozone enhancement, $\mathrm{CH}_{4}$ depletion, and the corresponding low tropopause altitude clearly support the evidence of vertical downward cross-tropopause stratospheric intrusions on 30 November.

The vertical cross section of ECMWF PV and specific humidity at 18:00 UT 30 November 2014 and the daily AIRS ozone on 30 November 2014, along a constant latitude $40^{\circ} \mathrm{N}$, 

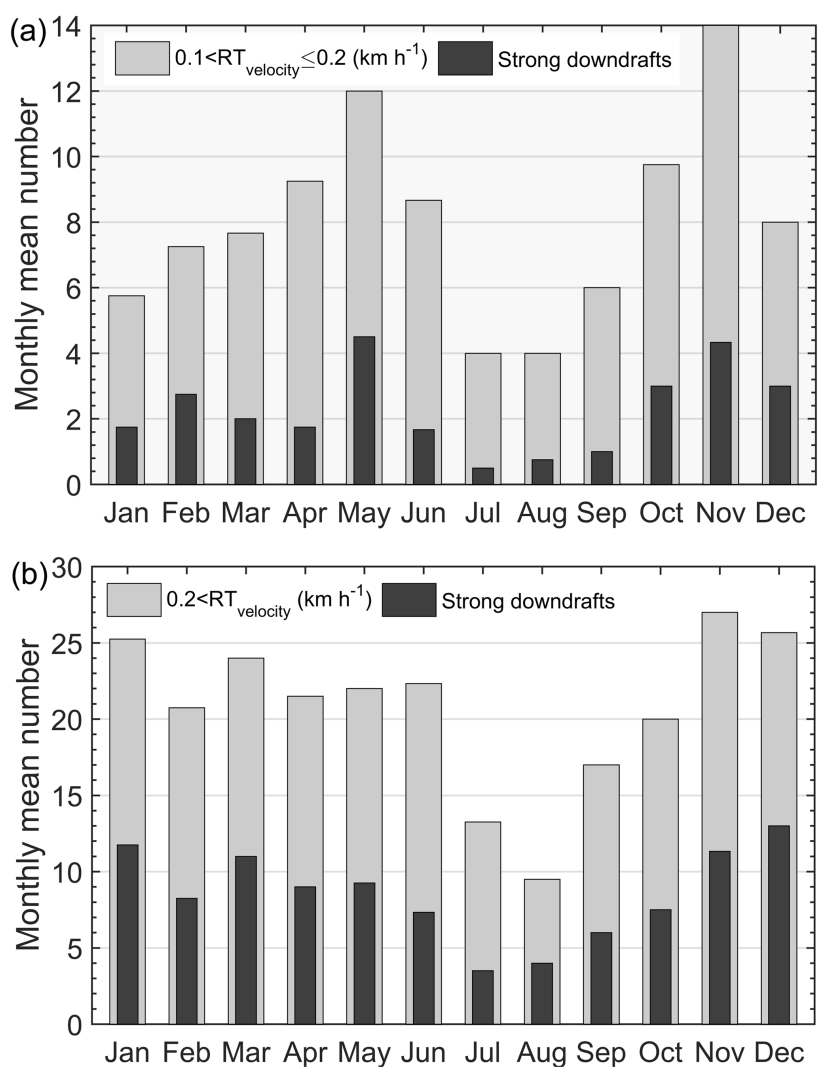

Figure 12. Four years (2012-2015) of radar-determined monthly mean number of rapid tropopause ascent (gray bands) and the corresponding strong downdrafts just preceding the rapid tropopause ascent (black bands). (a) Gray bands: ascent of at least $0.6 \mathrm{~km}$ and excursion velocity between 0.1 and $0.2 \mathrm{~km} \mathrm{~h}^{-1}$; black bands: except for the criteria of gray bands, strong downdrafts that occurred preceding the rapid RT ascent must exceed $0.5 \mathrm{~m} \mathrm{~s}^{-1}$ and pass through the RT layer. (b) Same as (a) but for the occasions when the ascent velocity is larger than $0.2 \mathrm{~km} \mathrm{~h}^{-1}$. According to the study here, the black bands in the histogram represent the occurrence of possible stratospheric intrusions well.

is shown in Fig. 8. Please note that the high PV and dry air have been observed intruding deep into the troposphere as low as $650 \mathrm{hPa}(\sim 3.6 \mathrm{~km})$, whereas the vertical structure of AIRS ozone has shown that the enhanced ozone intruded into the troposphere at $\sim 500 \mathrm{hPa}$. This difference in vertical scale of intrusion between ozone and PV parameters is most likely due to two reasons: (1) the local high PV value observed near $\sim 600 \mathrm{hPa}$ is not a true stratospheric characterized intrusion but rather adiabatically produced high PV (e.g., Skerlak et al., 2015); (2) the relatively poor vertical resolution of AIRS ozone data may have limited the refined observation of the intrusions. From this figure, however, it is clear that stratospheric air (dry ozone-rich and high PV) intrusions have indeed occurred and were observed (at least intruded downward into $\sim 500 \mathrm{hPa}$ ).

\subsection{Trajectory model analysis}

Figure 9 shows $30 \mathrm{~h}$ backward trajectories ending at the radar site at 18:00 UT 29 November (panel a) and at 18:00 UT 30 November (panel b). As expected, the air mass parcel is transported eastward horizontally before the occurrence of main downdrafts (Fig. 9a), whereas after the downdrafts, the trajectories clearly show downward intrusions originated from the western site of Lake Baikal. Furthermore, a huge dry intrusion is tracked according to the criterion (based on a Lagrangian method) in Raveh-Rubin (2017). Trajectory results further support the evidence of downward intrusions that are closely related with the main downdrafts.

On the other hand, $30 \mathrm{~h}$ forward trajectories starting at 00:00 UT 30 November (panel a) and 00:00 UT 1 December (panel b) are shown in Fig. 10. It is interesting to note that, from Fig. 10a before the passage of COL, the air parcels at $4 \mathrm{~km}$ are transported rapidly upward (by more than $4 \mathrm{~km}$ within $\sim 23 \mathrm{~h}$ ) and northeastward to the upper troposphere of eastern Siberia. This upward and poleward transport is associated with a warm conveyor belt (southerly flows dominate) that is located ahead of the COL. It contributes to the transport of the tropospheric moist and polluted air (such as aerosol) into the upper troposphere and even the lower stratosphere (e.g., Stohl et al., 2003; Sandhya et al., 2015). After the downdrafts, forward trajectories in Fig. 10b demonstrate that the dry intrusion air parcels continue to be transported downward and southeastward to the boundary layer or even the surface.

\subsection{Strong downdrafts preceding rapid tropopause ascent - discussion}

Figure 11a shows another 20 typical cases of strong downdrafts preceding rapid RT ascent for the period March 2012 and January 2015 (shown placed end to end); the LRT height (plotted by crosses) and the vertical velocity of the RT (plotted in orange line) are also plotted. These cases (marked by black rectangular boxes and labeled as $\mathrm{S} 1, \mathrm{~S} 2, \mathrm{~S} 3, \ldots$, and S20) are identified based on the following criteria: (1) the amplitude of the RT ascent should exceed $0.6 \mathrm{~km}$ (four range gates), (2) vertical velocities of the RT ascent exceed $0.1 \mathrm{~km} \mathrm{~h}^{-1}$, (3) the downdrafts that occurred preceding the RT ascent should be $>0.5 \mathrm{~m} \mathrm{~s}^{-1}$, (4) the height region of the downdrafts should pass through the RT layer. The criteria are put forward mainly to avoid the influence of the RT spikes. Figure $11 \mathrm{~b}$ shows the backward trajectories for the nine selected cases. Results show clear evidence of downward intrusions corresponding to the associated strong downdrafts. Their sources are mainly from western Siberia (western site of Lake Baikal), except for the Tr5 case. Moreover, according to AIRS daily $500 \mathrm{hPa}$ ozone distribution, most of the cases in Fig. 11a (except for the cases S14, S15, S16, S17, S20) were associated with significant ozone enhancement, indicating intrusions of stratospheric origin (as shown in the Sup- 
Table 2. Characteristics of the 20 cases shown in Fig. 11a.

\begin{tabular}{lllll}
\hline Cases & $\begin{array}{l}\text { Time } \\
\text { (year/month/day) }\end{array}$ & $\begin{array}{l}\text { Background } \\
\text { condition }\end{array}$ & $\begin{array}{l}\text { Vertical } \\
\text { velocity of } \\
\text { RT ascent }\end{array}$ & $\begin{array}{l}\text { 500 hPa ozone } \\
\text { enhancement }\end{array}$ \\
\hline S1 & $2012 / 03 / 06$ & Cutoff low & $>0.2 \mathrm{~km} \mathrm{~h}^{-1}$ & Enhanced \\
S2 & $2012 / 03 / 06$ & Cutoff low & $>0.2 \mathrm{~km} \mathrm{~h}^{-1}$ & Enhanced \\
S3 & $2012 / 03 / 12$ & Low/high trough & $>0.2 \mathrm{~km} \mathrm{~h}^{-1}$ & Enhanced \\
S4 & $2012 / 03 / 13$ & Low/high trough & $>0.2 \mathrm{~km} \mathrm{~h}^{-1}$ & Enhanced \\
S5 & $2012 / 04 / 05$ & Low/high trough & $>0.2 \mathrm{~km} \mathrm{~h}^{-1}$ & Enhanced \\
S6 & $2012 / 04 / 05$ & Low/high trough & $>0.2 \mathrm{~km} \mathrm{~h}^{-1}$ & Enhanced \\
S7 & $2012 / 04 / 06$ & Low/high trough & $>0.2 \mathrm{~km} \mathrm{~h}^{-1}$ & Enhanced \\
S8 & $2012 / 06 / 13$ & Cutoff low & $>0.2 \mathrm{~km} \mathrm{~h}^{-1}$ & Enhanced \\
S9 & $2012 / 06 / 13$ & Cutoff low & $>0.2 \mathrm{~km} \mathrm{~h}^{-1}$ & Enhanced \\
S10 & $2013 / 08 / 02$ & Cutoff low & $>0.2 \mathrm{~km} \mathrm{~h}^{-1}$ & Enhanced \\
S11 & $2013 / 08 / 02$ & Cutoff low & $>0.2 \mathrm{~km} \mathrm{~h}^{-1}$ & Enhanced \\
S12 & $2013 / 08 / 03$ & PV streamer & $>0.2 \mathrm{~km} \mathrm{~h}^{-1}$ & Enhanced \\
S13 & $2013 / 08 / 03$ & PV streamer & $>0.2 \mathrm{~km} \mathrm{~h}^{-1}$ & Enhanced \\
S14 & $2014 / 01 / 02$ & PV streamer & $>0.2 \mathrm{~km} \mathrm{~h}^{-1}$ & None \\
S15 & $2014 / 01 / 02$ & PV streamer & $>0.2 \mathrm{~km} \mathrm{~h}^{-1}$ & None \\
S16 & $2014 / 01 / 03$ & PV streamer & $0.1-0.2 \mathrm{~km} \mathrm{~h}^{-1}$ & None \\
S17 & $2014 / 01 / 04$ & Low/high trough & $>0.2 \mathrm{~km} \mathrm{~h}^{-1}$ & None \\
S18 & $2014 / 05 / 02$ & Low/high trough & $0.1-0.2 \mathrm{~km} \mathrm{~h}^{-1}$ & Enhanced \\
S19 & $2014 / 05 / 02$ & Low/high trough & $>0.2 \mathrm{~km} \mathrm{~h}^{-1}$ & Enhanced \\
S20 & $2015 / 01 / 03$ & PV streamer & $>0.2 \mathrm{~km} \mathrm{~h}^{-1}$ & None \\
\hline
\end{tabular}

plement Fig. S1). It is important to note that the RT excursion velocity values of the cases are not all above $0.2 \mathrm{~km} \mathrm{~h}^{-1}$, and some are lower than this value (e.g., cases S16 and S18). However, some form of stratospheric intrusions was exactly observed in such cases from both the trajectory and satellite results. Therefore, the threshold of vertical velocity of the RT ascent is set at $0.1 \mathrm{~km} \mathrm{~h}^{-1}$, rather than $0.2 \mathrm{~km} \mathrm{~h}^{-1}$ (Hocking et al., 2007). Large differences between RT and LRT are also interesting to note on some occasions when the RT changes rapidly (such as the occasion near 14 March 2012).

According to the meteorological chart, the synoptic situation of those cases identified in Fig. 11a is introduced. The cases S1, S2, S8, S9, S10, and S11 seem to have a close relationship with COL development; cases S3, S4, S5, S6, S7, S17, S18, and S19 seem to be associated with low or high trough systems (at $500 \mathrm{hPa}$ ). The remaining cases do not seem to be associated with any significant synoptic development. However, in terms of the distribution of isentropic $\mathrm{PV}$ (generally at $315 \mathrm{~K}$ in winter and $330 \mathrm{~K}$ in summer), we found that the remaining cases S12, S13, S14, S15, S16, and S20 appear to be associated with some form of stratospheric streamers and their breakup within the previous $48 \mathrm{~h}$ (not shown). Some cases (e.g., S1 and S2) that appear close on the same day were probably caused by the same system. The characteristics of the 20 cases, including the background synoptic condition, vertical velocity of the RT ascent, and
$500 \mathrm{hPa}$ ozone enhancement, have been summarized in Table 2 .

In the light of the present understanding, the strong downdrafts preceding the rapid RT ascent can serve as an important diagnostic for intrusion events, during various synoptic processes in any season. This characteristic will be of great use and play an important role in routine identification of stratospheric intrusions. Considering the duration of such downdrafts, a higher time resolution of radar observations will be more helpful. The present study has shown that the duration of most downdrafts is generally within $1.5-3 \mathrm{~h}$. We consider, therefore, that the radar resolution should be best within $1 \mathrm{~h}$.

Hocking et al. (2007) have reported that the rapid tropopause ascent $\left(>0.2 \mathrm{~km} \mathrm{~h}^{-1}\right)$ alone can be a useful diagnostic for potential intrusion events. However, using only the information of RT heights might lead to non-negligible errors, as mentioned above in the Introduction, and according to the observations in Fig. 11. Especially on occasions when the RT ascent is between 0.1 and $0.2 \mathrm{~km} \mathrm{~h}^{-1}$ but the corresponding true intrusions were observed, all such intrusion events will be neglected (maybe $\sim$ two per month; refer to Fig. 12a), whereas on some occasions when the RT ascent exceeds $0.2 \mathrm{~km} \mathrm{~h}^{-1}$, but without observing true intrusion events (e.g., He et al., 2011), these events will be misdiagnosed (maybe $\sim 13$ per month; refer to Fig. 12b). In this sense, using the unique MST radar observations of both the 
RT height variability and the vertical wind as a complementary signature for identifying possible intrusion events is very meaningful.

Figure 12 shows four years (2012-2015) of the events with rapid RT ascent (gray bands) and the events with strong downdrafts just preceding the rapid RT ascent (black bands). The identification criteria of such strong downdrafts are similar to that mentioned above and the events are classified according to different values of vertical velocity of the ascent. Among all the events with ascent velocity between 0.1 and $0.2 \mathrm{~km} \mathrm{~h}^{-1}$, about one-quarter (approximately two per month; Fig. 12a) were observed with strong downdrafts preceding them, whereas for the events with the ascent velocity $>0.2 \mathrm{~km} \mathrm{~h}^{-1}$, the proportion is about a half (approximately 10 per month; Fig. 12b). Here, according to the results above, the occurrence of the strong downdrafts just preceding the rapid RT ascent (black bands in Fig. 12) represents the occurrence of possible intrusions to a large degree. In this way, Fig. 12 indicates that the occurrence of possible intrusions exhibits distinct seasonal variations, with a maximum in winter and spring and a minimum in summer. This is because the mesoscale and small-scale atmospheric processes, such as cold air outbreaks, thunderstorms, and convective activities, are more active in winter and spring. They are important sources for downward stratospheric intrusions.

\section{Conclusions}

Detailed case analysis of the cross-tropopause stratospheric intrusions was carried out during a COL. Global reanalysis, satellite data, and HYSPLIT trajectories all showed consistent evidence of dry ozone-rich, high PV, and depleted $\mathrm{CH} 4$ air that penetrated downward into the free troposphere. The key signature of the stratospheric intrusions in the Beijing MST radar observations is the strong downdrafts just preceding the rapid RT ascent. The radar echo power decreased rapidly within the region of strong downdrafts, after which abnormal high aspect sensitivity was recorded in the troposphere. Such high aspect sensitivity served as another potential clue for the intrusions of stratospheric origin.

Based on the criteria mentioned in Sect. 3.5, 20 other typical cases of strong downdrafts preceding the rapid RT ascent between March 2012 and January 2015 were presented. These events occurred during different synoptic processes in different seasons. However, most of the cases (15 of them) are associated with some form of intrusions observed by a combination of AIRS-retrieved ozone and the HYSPLIT trajectory model. Our results show that the radarderived tropopause height and vertical winds are strong complementary indicators to be used to infer the occurrence of the intrusions of stratospheric origin. This will be of great use and play an important role in the routine identification or prediction of intrusion events. However, the actual origin of the observed downdrafts preceding the rapid RT ascent is not addressed in this paper. Further combinations of observational experiments need to be conducted, especially using ozonesonde soundings, to quantitatively analyze the effectiveness of the present identification criteria for possible intrusions.

Data availability. MST radar data are publicly and freely available at http://159.226.22.74/ (MST, 2018). AIRS data are publicly and freely available at https://disc.gsfc.nasa.gov/ (AIRS, 2018). ECMWF ERA-interim data are publicly and freely available at https://www.ecmwf.int/en/forecasts/datasets (ECMWF, 2018). Interpolated OLR data are available at https://www.esrl.noaa.gov/ psd/ (OLR, 2018). Global radiosonde data publicly and freely available at http://weather.uwyo.edu/upperair/ (Radiosonde, 2018). HYSPLIT Trajectory model are publicly available at https://www. arl.noaa.gov/ (HYSPLIT, 2018).

Supplement. The supplement related to this article is available online at: https://doi.org/10.5194/angeo-36-1403-2018-supplement.

Author contributions. GC, YT, SZ, and KH are the people in charge of MST radar data archiving, mage-generation and quality control. The HYSPLIT trajectory model analysis were performed by CS. The processing and data analysis for radar, satellite, and reanalysis data was developed by FC.

Competing interests. The authors declare that they have no conflict of interest.

Acknowledgements. The authors really appreciate Prof. Shira Raveh-Rubin for reading and commenting the manuscript. This work is funded by the National Natural Science Foundation of China (NSFC grants no. 41722404 and 41474132). The authors would like to thank the staff of the Chinese Meridian Space Weather Monitoring Project (CMSWMP) for their support in conducting the experiment. The authors sincerely acknowledge the ECMWF, NASA, and NOAA Air Resources Laboratory (ARL) for providing global reanalysis, satellite data, and the HYSPLIT transport model, respectively. The interpolated OLR data are provided by the NOAA/OAR/ESRL PSD, Boulder, Colorado, USA, from their website at https://www.esrl.noaa.gov/psd/ (last access: 17 October 2018). The MST radar data are available at the Data Centre for Meridian Space Weather Monitoring Project (http://159.226.22.74/; last access: 17 October 2018). The radiosonde data are available from http://weather.uwyo.edu/upperair/sounding.html (last access: 17 October 2018).

Edited by: Marc Salzmann

Reviewed by: two anonymous referees 


\section{References}

Alexander, S. P., Murphy, D. J., and Klekociuk, A. R.: High resolution VHF radar measurements of tropopause structure and variability at Davis, Antarctica $\left(69^{\circ} \mathrm{S}, 78^{\circ} \mathrm{E}\right)$, Atmos. Chem. Phys., 13, 3121-3132, https://doi.org/10.5194/acp-133121-2013, 2013.

Appenzeller, C., Holton, J. R., and Rosenlof, K. H.: Seasonal variation of mass transport across the tropopause, J. Geophys. Res.Atmos., 101, 15071-15078, 1996.

Butchart, N., Cionni, I., Eyring, V., et al.: Chemistry-climate model simulations of twenty-first century stratospheric climate and circulation changes, J. Clim., 23, 5349-5374, 2010.

Chen, P.,: Isentropic cross-tropopause mass exchange in the extratropics, J. Geophys. Res., 100, 16661-16673, 1995.

Chen, G., Cui, X., Chen, F., Zhao, Z., Wang, Y., Yao, Q., and Gong, W.: MST Radars of Chinese Meridian Project: System Description and Atmospheric Wind Measurement, IEEE T. Geosci. Remote, 54, 4513-4523, 2016.

Chipperfield, M. P., Bekki, S., Dhomse, S., Harris, N., Hassler, B., and Hossaini, R., Steinbrecht, W., Thiéblemont, R., and Weber, M.: Detecting recovery of the stratospheric ozone layer, Nature, 549, 211-218, 2017.

Das, S. S., Jain, A. R., Kumar, K. K., and Narayana, Rao D.: Diurnal variability of the tropical tropopause: Significance of VHF radar measurements, Radio Sci., 43, RS6003, https://doi.org/10.1029/2008RS003824, 2008.

Das, S. S., Ratnam, M. V., Uma, K. N., Subrahmanyam, K. V., Girach, I. A., Patra, A. K., Aneesh, S., Suneeth, K. V., Kumar, K. K., Kesarkar, A. P., Sijikumar, S., and Ramkumar, G.: Influence of tropical cyclones on tropospheric ozone: possible implications, Atmos. Chem. Phys., 16, 4837-4847, https://doi.org/10.5194/acp-16-4837-2016, 2016.

Dee, D. P., Uppala, S. M., Simmons, A. J., et al.: The ERA-Interim reanalysis: configuration and performance of the data assimilation system, Q. J. Roy. Meteor. Soc., 137, 553-597, 2011.

Elbern, H., Kowol, J., Sládkovic, R., and Ebel, A.: Deep stratospheric intrusions: a statistical assessment with model guided analyses, Atmos. Environ., 31, 3207-3226, 2006.

Fukao, S., Hashiguchi, H., Yamamoto, M.,, Tsuda, Nakamura, T., Yamamoto, M. K., Sato, T., Hagio, M., and Yabugaki, Y.: Equatorial Atmosphere Radar (EAR).: System description and first results, Radio Sci., 38, 1053, https://doi.org/10.1029/2002RS002767, 2003.

Gage, K. S. and Green, J. L.: Tropopause detection by partial specular reflection with Very-High-Frequency radar, Science, 203, 1238-1240, 1979.

Gerasopoulos, E., Zanis, P., Papastefanou, C., Zerefos, C. S., Ioannidou, A., and Wernli, H.: A complex case study of down to the surface intrusions of persistent stratospheric air over the Eastern Mediterranean, Atmos. Environ., 40, 4113-4125, 2006.

Grant, D. D., Fuentes, J. D., Delonge, M. S., Chan, S., Joseph, E., and Kucera, P., and Ndiaye, S. A.: Ozone transport by mesoscale convective storms in western senegal, Atmos. Environ., 42, 7104-7114, 2008.

He, H., Tarasick, D. W., Hocking, W. K., Carey-Smith, T. K., Rochon, Y., Zhang, J., Makar, P. A., Osman, M., Brook, J., Moran, M. D., Jones, D. B. A., Mihele, C., Wei, J. C., Osterman, G., Argall, P. S., McConnell, J., and Bourqui, M. S.: Transport analysis of ozone enhancement in Southern On- tario during BAQS-Met, Atmos. Chem. Phys., 11, 2569-2583, https://doi.org/10.5194/acp-11-2569-2011, 2011.

Hirschberg, P. A. and Fritsch, J. M.: A study of the development of extratropical cyclones with an analytic model. Part I: The effects of stratospheric structure, J. Atmos. Sci., 50, 311-327, 1993.

Hocking, W. K., Careysmith, T., Tarasick, D. W., Argall, P. S., Strong, K., Rochon, Y. J., Zawadzki, I., and Taylor, P. A.: Detection of stratospheric ozone intrusions by windprofiler radars, Nature, 450, 281-284, 2007.

Holton, J. R., Haynes, P. H., McIntyre, M. E., Douglass, A. R., Rood, R. B., and Pfister, L.: Stratospheretroposphere exchange, Rev. Geophys., 33, 403-439, https://doi.org/10.1029/95RG02097, 1995.

Hoskins, B. J., McIntyre, M. E., and Robertson, A. W.: On the use and significance of isentropic potential vorticity maps, Q. J. Roy. Meteor. Soc., 111, 877-946, 1985.

Jiang, Y. C., Zhao, T. L., Liu, J., Xu, X. D., Tan, C. H., Cheng, X. H., Bi, X. Y., Gan, J. B., You, J. F., and Zhao, S. Z.: Why does surface ozone peak before a typhoon landing in southeast China?, Atmos. Chem. Phys., 15, 13331-13338, https://doi.org/10.5194/acp-15-13331-2015, 2015.

Kim, K. E., Jung, E. S., Campistron, B., and Heo, B. H.: A physical examination of tropopause height and stratospheric air intrusion: a case study, J. Meteor. Soc. Jpn., 79, 1093-1103, 2001.

Kumar, K. K. and Uma, K. N.: High temporal resolution VHF radar observations of stratospheric air intrusions in to the upper troposphere during the passage of a mesoscale convective system over Gadanki $\left(13.5^{\circ} \mathrm{N}, 79.2^{\circ} \mathrm{E}\right)$, Atmos. Chem. Phys. Discuss., 9, 13843-13857, https://doi.org/10.5194/acpd-913843-2009, 2009.

Kumar, K. K.: VHF radar observations of convectively generated gravity waves: Some new insights, Geophys. Res. Lett., 33, 311330, https://doi.org/10.1029/2005GL024109, 2006.

Leclair de Bellevue, J., Baray, J. L., Baldy, S., Ancellet, G., Diab, R., and Ravetta, F.: Simulations of stratospheric to tropospheric transport during the tropical cyclone Marlene event, Atmos. Environ., 41, 6510-6526, 2007.

Lee, H.-T.: Climate Algorithm Theoretical Basis Document (CATBD): Outgoing Longwave Radiation (OLR) - Daily, NOAA's Climate Data Record (CDR) Program, CDRP-ATBD-0526, 46 pp., 2014.

Mahlman, J. D.: Dynamics of transport processes in the upper troposphere, Science, 276, 1079-1083, 1997.

Oltmans, S. J. and Levy II, H.: Seasonal cycle of surface ozone over the western North Atlantic, Nature, 358, 392-394, 1992.

Ottersten, H.: Mean vertical gradient of potential refractive index in turbulent mixing and radar detection of CAT, Radio Sci., 4, 1247-1249, 1969.

Price, J. D. and Vaughan, G.: The potential for stratospheretroposphere exchange in cut-off-low systems, Q. J. Roy. Meteor. Soc., 119, 343-365, 1993.

Ramaswamy, V., Schwarzkopf, M. D., and Shine, K. P.: Radiative forcing of climate from halocarbon-induced global stratospheric ozone loss, Nature, 355, 810-812, https://doi.org/10.1038/355810a0, 1992.

Rao, T. N., Arvelius, J., and Kirkwood, S.: Climatology of tropopause folds over a european arctic station (esrange), J. Geophys. Res.-Atmos., 113, 762-770, 2008. 
Raveh-Rubin, S.: Dry Intrusions: Lagrangian Climatology and Dynamical Impact on the Planetary Boundary Layer, J. Climate, 30, 6661-6682, 2017.

Ravindrababu, S., Venkat Ratnam, M., Sunilkumar, S. V., Parameswaran, K., and Krishna Murthy, B. V.: Detection of tropopause altitude using Indian MST radar data and comparison with simultaneous radiosonde observations, J. Atmos. Sol.-Terr. Phys., 121, 679-687, 2014.

Rolph, G. D.: Real-time Environmental Applications and Display sYstem (READY) Website, NOAA Air Resources Laboratory, Silver Spring, MD, http://www.arl.noaa.gov/ready/hysplit4.html (last access: 12 July 2018), 2003.

Sandhya, M., Sridharan, S., and Indira Devi, M.: Tropical upper tropospheric humidity variations due to potential vorticity intrusions, Ann. Geophys., 33, 1081-1089, https://doi.org/10.5194/angeo-33-1081-2015, 2015.

Skerlak, B., Sprenger, M., Pfahl, S., Tyrlis, E., and Wernli, H.: Tropopause folds in ERA-Interim: Global climatology and relation to extreme weather events, J. Geophys. Res., 120, 48604877, 2015.

Sørensen, J. H. and Nielsen, N. W.: Intrusion of stratospheric ozone to the free troposphere through tropopause folds - a case study, Phys. Chem. Earth Pt. B, 26, 801-806, 2001.

Sprenger, M., Croci Maspoli, M., and Wernli, H.: Tropopause folds and cross-tropopause exchange: a global investigation based upon ecmwf analyses for the time period march 2000 to february 2001, J. Geophys. Res.-Atmos., 108, 2003.

Stohl, A., Bonasoni, P., Cristofanelli, P., Collins, W., Feichter, J., and Frank, A., Forster, C., Gerasopoulos, E., GäGgeler, H., James, P., Kentarchos, T., Kromp-Kolb, H., Krüger, B., Land, C., Meloen, J., Papayannis, A., Priller, A., Seibert, P., Sprenger, M., Roelofs, G. J., Scheel, H. E., Schnabel, C., Siegmund, P., Tobler, L., Trickl, T., Wernli, H., Wirth, V., Zanis, P., and Zerefos, C.: Stratosphere-troposphere exchange: a review, and what we have Stohl, A., Bonasoni, P., Cristofanelli, P., Collins, W., Feichter, J., Frank, A., Forster, C., Gerasopoulos, E., GäGgeler, H., James, P., Kentarchos, T., Kromp-Kolb, H., Krüger, B., Land, C., Meloen, J., Papayannis, A., Priller, A., Seibert, P., Sprenger, M., Roelofs, G. J., Scheel, H. E., Schnabel, C., Siegmund, P., Tobler, L., Trickl, T., Wernli, H., Wirth, V., Zanis, P., and Zerefos, C.: Stratosphere-troposphere exchange: a review, and what we have learned from staccato, J. Geophys. Res.-Atmos., 108, 469-474, $2003 a$.
Stohl, A., Wernli, H., James, P., Bourqui, M., Forster, C., Liniger, M. A., Seibert, P., and Sprenger, M.: A new perspective of stratosphere troposphere exchange, B. Am. Meteorol. Soc., 84, 1565$1573,2003 b$

Stohl, A., Spichtinger-Rakowsky, N., Bonasoni, P., Feldmann, H., Memmesheimer, M., Scheel, H. E., Trickl, T., Hübener, S., Ringer, W., and Mandl, M.: The influence of stratospheric intrusions on alpine ozone concentrations, Atmos. Environ., 34, 1323-1354, 2000.

Stein, A. F., Draxler, R. R., Rolph, G. D., Stunder, B. J. B., Cohen, M. D., and Ngan, F.: Noaa's HYSPLIT atmospheric transport and dispersion modeling system, B. Am. Meteorol. Soc., 96, 20592077, 2016.

Stevenson, D. S., Dentener, F. J., Schultz, M. G., et al.: Multimodel ensemble simulations of present-day and near-future tropospheric ozone, J. Geophys. Res.-Atmos., 111, 263-269, 2006.

Susskind, J., Barnet, C. D., and Blaisdell, J. M.: Retrieval of atmospheric and surface parameters from AIRS/AMSU/HSB data in the presence of clouds, IEEE T. Geosci. Remote, 41, 390-409, https://doi.org/10.1109/tgrs.2002.808236, 2003.

Wang, C.: New Chains of Space Weather Monitoring Stations in China, Space Weather, 8, 1-5, 2010.

World Meteorological Organization (WMO): Atmospheric ozone 1985, WMO Global Ozone Res. Monit. Proj. Rep. 20, Geneva, Switzerland, 1986.

Xiong, X., Barnet, C., Maddy, E., Wofsy, S. C., Chen, L., Karion, A., and Sweeney, C.: Detection of methane depletion associated with stratospheric intrusion by atmospheric infrared sounder (AIRS), Geophys. Res. Lett., 40, 2455-2459, https://doi.org/10.1002/grl.50476, 2013.

Yamamoto, M., Oyamatsu, M., Horinouchi, T., Hashiguchi, H., and Fukao, S.: High time resolution determination of the tropical tropopause by the Equatorial Atmosphere Radar, Geophys. Res. Lett., 30, 267-283, 2003. 